\title{
Legal ambiguities surround authority to make end-of-life decisions
}

$\mathrm{S}$ hould physicians have to seek consent from patients, substitute decision-makers or an independent tribunal in order to pull the plug on life-sustaining treatments they deem futile?

An informal survey of Canadian case law indicates that courts have been all over the map on the issue, which has recently resurfaced in the headlines as part of a dispute between two physicians at the Sunnybrook Health Sciences Centre in Toronto, Ontario and the family of a comatose man (www.cmaj.ca/lookup/doi/10 .1503/cmaj.109-3855).

The decision, which could radically alter how end-of-life decisions must be made in Ontario, pivots on the question of who should call the shots at end-of-life, an issue that has divided physicians, ethicists and legal minds for decades.

The Ontario case involves 59-year-old Iranian mechanical engineer Hassan Rasouli, who has been in a coma since he contracted bacterial meningitis following brain surgery at Sunnybrook in October, 2010. Physicians Dr. Brian Cuthbertson and Dr. Gordon Rubenfeld say Rasouli is in a permanent vegetative state and want to withdraw life support to prevent him dying a slow death from complications of being bedridden. But Rasouli's family has refused their consent, arguing that his religious beliefs should be respected and that, as a devout Shia Muslim, he should be kept alive on mechanical support "until all signs of life are gone" (www.can lii.org/en/on/onsc/doc/2011/2011onsc 1500/2011onsc1500.html).

The Ontario Court of Appeal is now deliberating whether to overturn a
Superior Court ruling in April that would require doctors to obtain consent from patients or their substitute deci-

Toronto lawyer intervening in the case and former adjudicator for the Consent and Capacity Board. "The fear is they'll end up with an intensive care unit full of people whose wishes, values or beliefs mean they have to be kept alive to suffer."

Conversely, if Cuthbertson and Rubenfeld's appeal is successful, it will set a major precedent that will allow Ontario doctors to make unilateral decisions about treatment at end-of-life, with or without consideration for patients' wishes, values or religious beliefs, Handelman argues. "I would be astonished to ever see another end-of-life case go before the Consent and Capacity Board. Why bother?"

Ontario is the only province with a Consent and Capacity Board. Elsewhere in Canada, patients or their families are forced to go to court to challenge doctors.

Handelman says Canadian doctors are generally required by various provincial statutes to obtain consent to administer "treatment" but there's little consensus in common law whether "treatment" includes decisions to cease treatment when a patient is terminally ill or has little chance of survival.

A 1997 decision from the

sion-makers to withdraw life-sustaining treatment, or failing that, take all disputed cases to the province's Consent and Capacity Board for mediation.

The physicians believe that the lower court ruling would effectively force doctors to continue treatment as long as a patient or patient's surrogate desires, even in cases where it may not provide medical benefit or could even harm the patient, explains Mark Handelman, a
Manitoba Court of Appeal ruled "there is no legal obligation on a medical doctor to take heroic measures to maintain the life of a patient in an irreversible vegetative state" (www.canlii .org/en/mb/mbca/doc/1997/1997canlii 3742/1997canlii3742.html).

Similarly, forcing doctors to act contrary to what they deem their "fundamental duty" to patients would be an "abuse of power," stated a 2008 ruling of 
the Supreme Court of British Columbia (www.canlii.org/en/bc/bcsc/doc/2008 /2008bcsc318/2008bcsc318.html).

Ontario's Superior Court ruled the same year that the decision to withdraw or withhold life support is inherently a medical one "within the sole purview of a patient's doctor," and that "consent is not needed for the doctors to make use of their professional judgment and discretion to cease treatment or give only palliative care" (www.canlii.org /en/on/onsc/doc/2008/2008canlii49154 /2008canlii49154.html).

The court failed, however, to consider the province's Health Care Consent Act, which includes a definition of "treatment" that "may, in addition, provide for the withholding or withdrawal of treatment in light of the person's current health condition" (www.e-laws.gov.on .ca/html/statutes/english/elaws_statutes _96h02_e.htm).

In other cases, Canadian courts have also rejected the notion that end-of-life decisions fall entirely within the unilateral purview of doctors.

In 1998, Manitoba's Court of Queen's Bench indicated that there is a need for independent review of such decisions before a physician pulls the plug as a mechanism for protecting and reassuring patients and their families (www.canlii.org/en/on/onsc/doc/2011 /2011onsc1500/2011 onsc1500.html).

The same court asserted in allowing an injunction to prevent doctors from removing a patient from a ventilator in 2008 that "physical contact with the patient's body" is one of the "crucial circumstances requiring consent," and that "the removal of the ventilator probably involves some interaction with the plaintiff's body" (www.canlii.org/en /mb/mbqb/doc/2008/2008mbqb49/2008 mbqb49.html).

The case law is ambiguous, in part, because very few end-of-life disputes ever make it to trial, Handelman says. "The patients almost always die before the hearing takes place."

Ontario's Consent and Capacity Board provides a relatively quick and inexpensive mediation process that will likely disappear if doctors are granted the unilateral authority to withdraw or withhold treatment at end-of-life, he adds. "It's forcing families into a corner, and wasting resources with the delay of getting in front of a judge."

Physicians and ethicists are also divided over how to balance medical benefit with a patient's wishes and beliefs in determining their best interest.

"It's reasonable for there to be increased legal recognition that there's a standard of care, in which some treatments are options and some are not," explains Dr. Laura Hawryluck, medical advisor to Ontario's critical care secretariat. "No doctor wants to feel they're responsible for adding to the suffering of someone who is already in a difficult situation."

But allowing doctors to bypass the Consent and Capacity Board is "maybe too easy an out" from having to work through uncomfortable decisions with patients and their families, says Dr. Ellen Tsai, a pediatric interventionist at Kingston General Hospital in Kingston, Ontario. "We don't have to live with the decisions. If I take someone off the ven- tilator and they die, I go on and continue my work. For that family, however, how do they come to terms with that?"

Some physicians may still seek consent from patients or their families, or try to weigh their patients' wishes and beliefs in making decisions to withhold or withdraw treatments, but such consideration would be entirely at the individual physician's discretion and would vary from doctor to doctor, says Rhonda Wiebe, cochair of the Council of Canadians with Disabilities end-of-life ethics committee.

Moreover, "some decisions have to be made really quickly and a physician may have to eyeball someone and make a decisions in a matter of hours," forcing even those with the best of intentions to momentarily overlook such considerations, or even their own nonmedical biases against continuing care, Wiebe adds. — Lauren Vogel, CMAJ

CMAJ 2011. DOI:10.1503/cmaj.109-3910

Editor's note: Fourteenth of a series on end-of-life care

Part I: Preparing for the inevitable (www.cmaj.ca/lookup/doi/10.1503/cmaj.109-3704)

Part II: Advance directives: Obstacles in preparing for the worst (www.cmaj.ca/lookup/doi/10.1503/cmaj.109-3743)

Part III: End-of-life planning framework calls for fewer checklists, more conversation (www.cmaj.ca/lookup/doi/10.1503/cmaj.109-3746)

Part IV: Tools help patients tackle tough choices for end-of-life care (www.cmaj.ca/lookup/doi/10.1503/cmaj.109-3750)

Part V: National home care standards urged (www.cmaj.ca/lookup/doi/10.1503/cmaj.109-3731)

Part VI: Access to palliative care varies widely across Canada (www.cmaj.ca/lookup/doi/10.1503/cmaj.109-3763)

Part VII: Framework urges physicians to proceed with caution on palliative sedation (www.cmaj.ca/lookup/doi/10.1503/cmaj.109-3766)

Part VIII: Pocket-sized help for people with dementia (www.cmaj.ca/lookup/doi/10.1503/cmaj.109-3705)

Part IX: Grief therapy for those left behind (www.cmaj.ca/lookup/doi/10.1503/cmaj.109-3793)

Part X: Providing hospice in the womb (www.cmaj.ca/lookup/doi/10.1503/cmaj.109-3776)

Part XI: Providing palliative care to the homeless (www.cmaj.ca/lookup/doi/10.1503/cmaj.109-3756)

Part XII: England examines funding options for end-of-life care (www.cmaj.ca/lookup/doi/10.1503/cmaj.109-3849)

Part XIII: Paramedic program reducing emergency room congestion (www.cmaj.ca/lookup/doi/10.1503/cmaj.109-3897) 